\title{
Experimental sand burial affects seedling survivorship, morphological traits, and biomass allocation of Ulmus pumila var. sabulosa in the Horqin Sandy Land, China
}

\author{
Jiao Tang ${ }^{1,2}$, Carlos Alberto Busso ${ }^{3}$, Deming Jiang ${ }^{1}$, Ala Musa ${ }^{1}$, Dafu Wu ${ }^{4}$, Yongcui Wang ${ }^{1}$, and Chunping Miao ${ }^{1,2}$ \\ ${ }^{1}$ Institute of Applied Ecology, Chinese Academy of Sciences, Shenyang, 110016, China \\ ${ }^{2}$ University of Chinese Academy of Sciences, Beijing, 100048, China \\ ${ }^{3}$ Departamento de Agronomía-CERZOS (CONICET: Consejo Nacional de Investigaciones Científicas y Tecnológicas \\ de la República Argentina), Universidad Nacional del Sur, San Andrés 800, 8000 Bahía Blanca, Argentina \\ ${ }^{4}$ Department of Resource and Environment, Henan Institute of Science and Technology, Xinxiang, 453003, China
}

Correspondence to: Deming Jiang (jiangdeming2016@163.com)

Received: 23 March 2016 - Published in Solid Earth Discuss.: 31 March 2016

Revised: 20 June 2016 - Accepted: 24 June 2016 - Published: 18 July 2016

\begin{abstract}
As a native tree species, Ulmus pumila var. sabulosa (sandy elm) is widely distributed in the Horqin Sandy Land, China. However, seedlings of this species have to withstand various depths of sand burial after emergence because of increasing soil degradation, which is mainly caused by overgrazing, climate change, and wind erosion. An experiment was conducted to evaluate the changes in its survivorship, morphological traits, and biomass allocation when seedlings were buried at different burial depths: unburied controls and seedlings buried vertically up to $33,67,100$, or $133 \%$ of their initial mean seedling height. The results showed that partial sand burial treatments (i.e., less than $67 \%$ burial) did not reduce seedling survivorship, which still reached $100 \%$. However, seedling mortality increased when sand burial was equal to or greater than $100 \%$. In comparison with the control treatment, seedling height and stem diameter increased at least by 6 and $14 \%$ with partial burial, respectively. In the meantime, seedling taproot length, total biomass, and relative mass growth rates were at least enhanced by $10,15.6$, and $27.6 \%$, respectively, with the partial sand burial treatment. Furthermore, sand burial decreased total leaf area and changed biomass allocation in seedlings, partitioning more biomass to aboveground organs (e.g., leaves) and less to belowground parts (roots). Complete sand burial after seedling emergence inhibited its reemergence and growth, even leading to death. Our findings indicated that seedlings of sandy elm showed some resis-
\end{abstract}

tance to partial sand burial and were adapted to sandy environments from an evolutionary perspective. The negative effect of excessive sand burial after seedling emergence might help in understanding failures in recruitments of sparse elm in the study region.

\section{Introduction}

Soil genesis is the pivotal process that determines the evolution of the soil system, and it offers services and resources to mankind (Berendse et al., 2015; Niu et al., 2015). Simultaneously, disturbances (such as land-use intensification and overgrazing) have a profound impact on the soil genesis process because of the increase in population and consumption (Borreli et al., 2016; Brevik et al., 2015; Verheijen et al., 2009; Wang et al., 2016). Excessive human interferences change soil hydrological, geochemical, and biological cycles, inducing serious land degradation such as acidification, salinization, and desertification (Bellamy et al., 2005; Colazo and Buschiazzo, 2015; Foley et al., 2005; Gabarrón-Galeote et al., 2013; Smith et al., 2015). Desertification, the main significant type of land degradation, appears widely around the world, especially in arid and semi-arid lands (Jiang et al., 2003).

In northern China, the total desert area caused by wind erosion increased $181 \%$ from $1955\left(0.137\right.$ million $\left.\mathrm{km}^{2}\right)$ to 
$2000\left(0.386\right.$ million $\left.\mathrm{km}^{2}\right)$, and more than $84 \%$ of the total desert land was the result of wind erosion at the beginning of the 21 st century. So it is urgent to combat land degradation resulting from wind erosion in China (Wang et al., 2015). Fortunately, there has been some reversal of this land degradation as a result of wind erosion because sustainable and effective measures have been completed in the local regions within the last couple of decades (Gao et al., 2015; Qu et al., 2012). Before designing reasonable strategies for controlling land degradation, it is important to understand the spatial and temporal patterns in land susceptibility to wind erosion (Borreli et al., 2016). Colazo and Buschiazzo (2015) reported that the tillage and wind erosion caused the breakdown of soil aggregates, and wind removed fine particles (e.g., clay) easily, increasing the soil susceptibility of being further degraded in the semi-arid pampas of Argentina. Gao et al. (2016) showed than an optimal choice in agricultural practices was no tillage with stubble retention in regions exposed to frequent, strong winds and drought events. Stubble retention prevented soil organic carbon from wind erosion not only by physical protection but also by increased soil moisture, which favored soil aggregate formation, thus reducing soil erosion by wind. Another successful measure to control wind erosion in farmlands included planting wind-shelter forests, which reported that some native tree species were used for this purpose in the western regions of northern China (Wang et al., 2015). Particles eroded by wind could be transported and accumulated from several to hundreds of meters downwind. These particles might bury vegetation to different depths as a result. However, the effects of various vegetation sand burial depths on the native species' survivorship and morphological traits are unknown. This information is very important for helping to fight against desertification.

As the largest sandy land in China, the Horqin Sandy Land, shaped in the middle the Pleistocene period, is located in the southeast of the Mongolian Plateau (Qiu, 1989). Because of climatic changes (rainfall distribution and global warming) and excessive human disturbances (i.e., overutilization of renewable natural resources), vegetation degradation and land desertification have become more obvious in the past 50 years (Cao et al., 2008; Jiang et al., 2003; Zhang et al., 2004). An increasing number of pastures have deteriorated and transformed into semi-fixed and active dunes, inducing a lack of vegetation coverage. Sand moves fast in the horizontal or vertical space - the effects of strong winds during spring and summer - leading to different burial depths, which might range from 0.5 to $56.0 \mathrm{~cm}$ (Liu et al., 2014).

Vegetation and soil are momentous components of the terrestrial ecosystem (Berendse et al., 2015). It is well known that vegetation plays an important role in controlling soil genesis and degradation in fragile ecosystems such as estuarine, desert, and sandy lands (Berendse et al., 2015; Cerdà, 1998; Miao et al., 2014). Moreover, vegetation functional traits (e.g., morphology and establishment) in response to environmental stress (e.g., nutrient deficiency, water deficit, high irradiance, extreme temperatures) might be important for life history adaptive strategies (Miner et al., 2005; Wang et al., 2014). Plants usually have to face a trade-off between survival and growth in response to environmental changes by regulating their phenotypic plasticity (e.g., biomass allocation, relative growth rate) and/or physiological traits (e.g., antioxidant enzyme activities, membrane permeability, contents of osmotic substance; Li et al., 2015; Qu et al., 2012; Tian et al., 2015; Wu et al., 2013).

In sandy ecosystems, instability of the soil surface is one of the most damaging factors to biological activity. Furthermore, a sparse vegetation cover and a loose soil texture are highly susceptible to sand movements (Liu and Guo, 2005; Yan et al., 2005). Sand movement, the most direct evidence of land degradation, is regarded as a selective force determining colonization, establishment, and development of vegetation (Maun, 1994; Maun and Lapierre, 1986). Plants might respond differently to various degrees of sand burial and evolve different regenerative adaptations during the periods of soil seed bank formation, seed germination, and seedling emergence and development (Li et al., 2014; Qian et al., 2015; Tang et al., 2016).

As an indigenous species, Ulmus pumila var. sabulosa (sandy elm) has been widely distributed in the leeward slope of fixed and semi-fixed sand dunes and became the main component of sparse woodlands in the Horqin Sandy Land (Jiang et al., 2013; Tang et al., 2013, 2014). Since prehistoric times, it has been closely related to human life, providing hardwood for farming tools and furniture; fuel for nomads; and fodder from its tender leaves, young fruits, and edible bark (Ma, 1989; Schlütz et al., 2008). In addition, the sparseelm woodlands not only offer shelter for wildlife and domestic animals and a suitable environment for psammophytes but also protect the soil from wind erosion and burial, providing a very important ecological and social function in these arid and semi-arid lands (Yang et al., 2003). Although we realize the effects of sand burial on establishment of sandy elm, much of our comprehension and recognition to date come from ocular observations at the field rather than from controllable experiments (Maun, 1997). For example, we observed that plenty of non-dormant, dispersed sandy elm seeds germinated and seedling emergence occurred in the late spring, but few surviving seedlings were detected in the following field surveys of the degraded sparse woodlands. That phenomenon is hampering their recruitments and will have negative effects on future community structure of these woodland ecosystems.

Studies on the effects of sand burial have been widely reported in the fields of seedling survival (Belcher, 1977; Cheplick and Grandstaff, 1997; Harris and Davy, 1987; Li et al., 2015; Liu et al., 2008; Perumal and Maun, 2006), physiological characteristics (Shi et al., 2004; Wang et al., 2012; Zhao et al., 2015), and reproductive strategies (Liu et al., 2014; Sun et al., 2014; Zhao et al., 2007) on coastal marshes and wetlands plants. In general, it appears to be a thresh- 


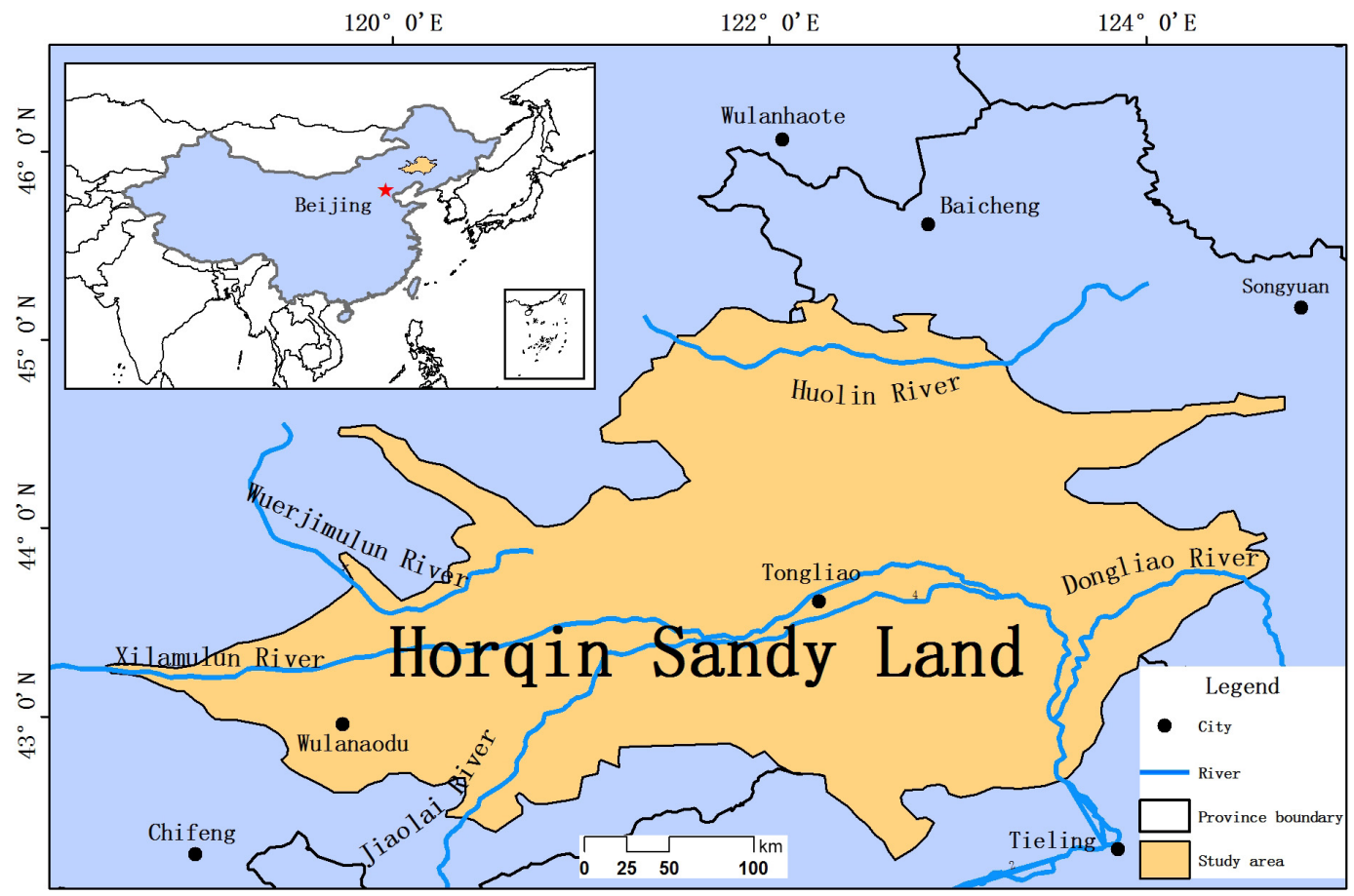

Figure 1. The geographic location of study area in the Horqin Sandy Land, China.

old sand burial depth for each plant species to maintain its vigor and subsequent sustained growth (Maun, 1997). Below that burial level, plant emergence and development have been promoted by increasing sand burial depth $(\mathrm{Qu}$ et al., 2012; Yang et al., 2007). Above the threshold, a deterioration of seedling vigor and reduced growth has occurred, even leaded to seedling death (Maun, 1997; Maun and Lapierre, 1986). However, no research has been conducted on the effects of continual sand accumulation on sandy elm seedlings after emergence to date, perhaps because of the limited area of sparse-elm woodland. Because of this, we investigated the effects of experimental sand burial on seedling survivorship and growth of sandy elm. The main objectives of this study were (1) to evaluate the effect of sand burial on seedling survivorship; (2) to assess the changes on seedling morphological traits and biomass allocation in response to sand burial; and (3) to explain the failure of sandy elm regeneration and provide a theoretical basis for successful recruitments and vegetation establishments on sandy elm woodlands.

\section{Materials and methods}

\subsection{Study site}

The experiment was conducted at the Wulanaodu Desertification Experimental Station of the Institute of Applied Ecology, Chinese Academy of Sciences $\left(43^{\circ} 02^{\prime} \mathrm{N}, 119^{\circ} 39^{\prime} \mathrm{E}\right.$, $480 \mathrm{~m}$ a.s.1.), located in the western Horqin Sandy Land,
China (Fig. 1). This site experiences a temperate continental climate. Mean annual temperature and precipitation are $7.3^{\circ}$ and $315 \mathrm{~mm}$, respectively. Almost $75 \%$ of precipitation occurs from June to September during the growing season. Annual average wind speed is $4.4 \mathrm{~m} \mathrm{~s}^{-1}$; the windy season is from March to June (Liu et al., 2012; Miao et al., 2014). The landscape is characterized by sparse woodlands, sand dunes, and lowland areas. The dominant soils are eolian soils, and major plant species include some shrubs (e.g., Salix gordejevii and Caragana microphylla) and annual and perennial herbs (e.g., Bassia dasyphylla, Agriophyllum squarrosum; Cao et al., 2011).

\subsection{Experimental methods}

In mid-May 2015, sandy elm seeds were first collected from multiple mature individuals and then mixed altogether. After careful selection, uniform and intact seeds were chosen and sowed in plastic pots $(45 \mathrm{~cm}$ diameter, $30 \mathrm{~cm}$ height $)$. Sandy soil was taken from nearby woodlands, and it was sieved to remove debris and branches. All seeds were covered by sand to a depth of $0.5-1.0 \mathrm{~cm}$. In a parallel study, we found that depth was the most suitable, promoting the greatest percentage and speed of seedling emergence for sandy elm (Tang et al., 2016). Holes in the bottom of the pots were covered with nylon mesh to prevent soil loss, while allowing drainage of water. All pots were watered every 3 days to keep the soil moist. Twenty days after sowing, 8 to 12 seedlings emerged; eight similar seedlings were retained in 
each pot, and the rest were removed. Mean seedling height $(5.4 \pm 0.5 \mathrm{~cm})$ was obtained after measuring the height of each seedling in every pot. Afterwards, seedlings were experimentally buried to either 0 (T0, no burial, control treatment) or $33 \%(\mathrm{~T} 33 ; 1.8 \mathrm{~cm}), 67 \%(\mathrm{~T} 67 ; 3.6 \mathrm{~cm}), 100 \%$ (T100; $5.4 \mathrm{~cm})$, or $133 \%(\mathrm{~T} 133 ; 7.2 \mathrm{~cm})$ soil depth of the original, overall mean seedling height. For this purpose, sandy soil was added to the pots according to the different burial depths. Each seedling was kept vertical while buried. Six replicates were used per treatment, so there was a total of 30 pots in this experiment. Meanwhile, 15 randomly selected seedlings were harvested to determine the original measurements for growth analysis before sand burial.

Surviving seedlings were counted after 45 days of treatment initiation. They were considered alive when fresh phloem occurred in both stem and roots, and green tissue on leaf blades. Seedling height was first measured from the new soil surface level to the seedling apex and then marked immediately. Stem diameter was measured close to the burial surface using a vernier caliper. In the meantime, 15 randomly selected seedlings were dug out in each treatment; roots were picked up as intact as possible from the sandy soil. Taproot lengths were measured, and total leaf area was obtained using a portable area meter (Li-Cor3000A, Lincoln, Nebraska, USA). Finally, plant organs (i.e., leaves, stems, and roots) were dried at $80^{\circ} \mathrm{C}$ and weighed after reaching a constant mass for each seedling in the laboratory.

\subsection{Calculations}

The (1) relative height growth rate (RHGR, $\mathrm{mm} \mathrm{cm}^{-1} \mathrm{~d}^{-1}$ ) and (2) relative mass growth rate (RMGR, $\mathrm{mg} \mathrm{mg}^{-1} \mathrm{~d}^{-1}$ ) of seedlings were calculated according to the following equations (Walck et al., 1999; Zhao et al., 2007):

$$
\begin{aligned}
\text { RHGR } & =\frac{H_{2}-H_{1}}{H_{1}\left(T_{2}-T_{1}\right)}, \\
\text { RMGR } & =\frac{\ln M_{2}-\ln M_{1}}{T_{2}-T_{1}},
\end{aligned}
$$

where $H_{2}$ and $H_{1}$ were seedling heights at the end and beginning (i.e., immediately before sand burial) of the experiment, respectively; $M_{2}$ or $M_{1}$ were the total dry biomass of seedlings either after 45 days from study initiation or just before sand burial, respectively; ln was the natural logarithm; and $T_{2}-T_{1}$ was time from sand burial (i.e., 45 days).

\subsection{Statistical analysis}

All data were tested for normality and homogeneity of variance prior to analysis. Data were log-transformed if necessary (Sokal and Rohlf, 1995). The effects of experimental sand burial on seedling height, RHGR, plant stem diameter, total leaf area, RMGR, dry biomass, and percentage biomass allocation were evaluated by one-way ANOVA. Whenever F tests were significant, Tukey's test was used to compare treatment means at $P<0.05$. All statistical analyses used SPSS

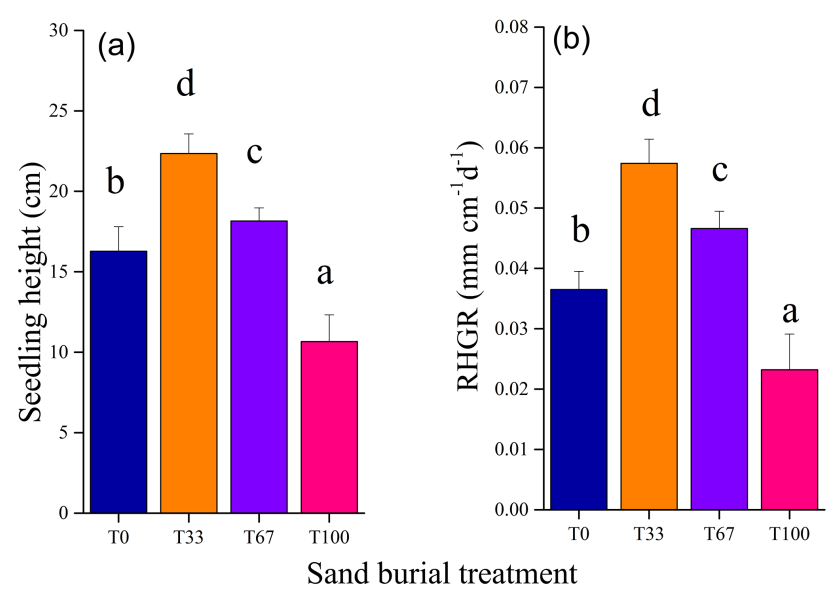

Figure 2. Seedling height and relative growth rate for height (RHGR) of Ulmus pumila var. sabulosa exposed to various sand burial treatments during a 45-day growth period. These treatments included sand burial of seedlings to a depth equivalent to 33 (T33), 67 (T67), or $100 \%$ (T100) of the mean seedling height at the initiation of the study (see the Material and methods section for further details). Each histogram is the mean \pm 1 standard error (SE) of $n=15$. Different letters above histograms among seed burial depths are significantly different at $P<0.05$.

21.0 (SPSS Inc., Chicago, USA), and drawings were made using Origin Pro 9.0 (Origin Lab Corp, USA).

\section{Results}

\subsection{Effects of permanent sand burial on seedling survival}

The effect of sand burial depth on seedling survival was significant $\left(F_{4,25}=38.339, P<0.001\right)$. During the whole study, seedling survival was $100 \%$ in the unburied (T0) and partialburial treatments (T33, T67). Simultaneously, seedling survival $(84.48 \pm 8.8 \%)$ was significantly lower in the complete sand burial treatment (T100) than in the control treatment. No seedling survived after burial depth exceeded the overall mean original height of seedlings (i.e., in T133).

\subsection{Changes of morphological seedling traits in response to sand burial}

Seedling height was significantly affected by sand burial depths after 45 days of burial $\left(F_{3,56}=139.978, P<0.001\right)$. The greatest seedling height was observed in the T33 treatment, which was significantly greater than that in the T67 treatment (Fig. 2a; $P<0.05$ ). Height of seedlings in the control treatment was significantly lower than that in the T33 and T67 treatments (i.e., $10.66 \pm 0.66 \mathrm{~cm}$; Fig. $2 \mathrm{a}, P<0.05$ ).

The relative height growth rate of seedlings was significantly affected $\quad\left(F_{3,56}=286.877 ; \quad P<0.001\right)$ after 45 days of sand burial (Fig. 2b). The high- 

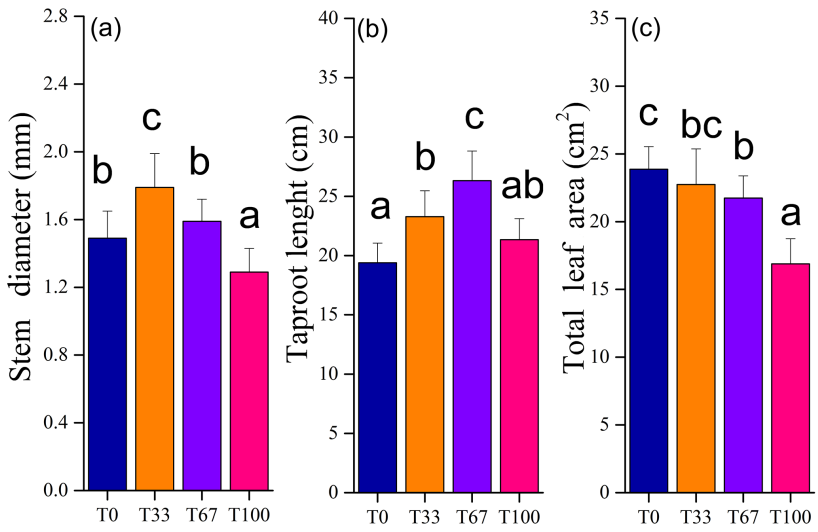

Sand burial treatment

Figure 3. Stem diameter, taproot length, and total leaf area on seedlings of Ulmus pumila var. sabulosa exposed to various sand burial treatments during a 45-day growth period. These treatments included sand burial of seedlings to a depth equivalent to 33 (T33), 67 (T67), or $100 \%$ (T100) of the mean seedling height at the initiation of the study. Each histogram is the mean \pm 1 SE of $n=15$. Different letters above histograms among seed burial depths are significantly different at $P<0.05$.

est $\quad\left(0.057 \pm 0.004 \mathrm{~mm} \mathrm{~cm}^{-1} \mathrm{~d}^{-1}\right) \quad$ and lowest $\left(0.023 \pm 0.006 \mathrm{~mm} \mathrm{~cm}^{-1} \mathrm{~d}^{-1}\right)$ relative growth rates for seedling height were shown in the T33 and T100 treatments, respectively (Fig. 2b). The pattern of change with burial depth was similar to that described for seedling height (Fig. 2a); values were greater in the control than $100 \%$ covered by sand (Fig. $2 \mathrm{~b} ; P<0.05$ ).

After 45 days from initiation of the study, stem diameter $\left(F_{3,56}=26.669, P<0.001\right)$, taproot length $\left(F_{3,56}=30.942\right.$, $P<0.001)$, and total leaf area $\left(F_{3,56}=35.961, P<0.001\right)$ of seedlings were also affected by sand burial (Fig. 3a, b, c). Stem diameter was $20 \%$ greater $(P<0.05)$ in the T33 than in the T0 treatment (Fig. 3a). However, stem diameters were similar in the control and T67 treatments (Fig. 3a, $P>0.05)$. Values in the T100 treatment, nevertheless, were $13.4 \%$ lower than those in the unburied control (Fig. 3a). While taproot length was lowest in the control treatment, it was highest in the T67 treatment (Fig. 3b; 35.7\% higher than that in the control; $P<0.05)$. The total leaf area of seedlings was significantly greater in the control than in the T67 and T100 treatments (Fig. 3c; $P<0.05$ ). The lowest total leaf area, however, was found in the T100 treatment (Fig. 3c).

\subsection{Effects of sand burial on biomass growth and relative mass growth rate}

There were significant differences in total seedling biomass $\left(F_{3,56}=129.949, \quad P<0.001\right)$ and its component organs (e.g., leaves $\left(F_{3,56}=93.965, P<0.001\right)$, and roots $\left.\left(F_{3,56}=50.474, P=0.002\right)\right)$ after the experiment. The only exception was for seedling stem biomass $\left(F_{3,56}=2.017\right.$,
$P=0.122$ ), which was similar in all sand burial treatments (Table 1). Seedling organs also showed a similar pattern in their dry biomass. Greatest total biomasses were reached in the T33 and T67 treatments (Table 1). Total biomass of seedlings was significantly lower in T100 treatment than in those treatments (Table 1). Patterns shown for the biomasses of leaves and roots among treatments were similar to those shown for the total biomass of seedlings (Table 1).

Significant differences were found in allocation of seedling biomass to leaves $\left(F_{3,56}=12.841, P<0.001\right)$, stems $\left(F_{3,56}=27.579, P<0.001\right)$ and roots $\left(F_{3,56}=7.594\right.$, $P<0.001)$. On leaves, percentage biomass allocation was greatest in the T33 and T67 treatment, and lowest in the control and T100 treatments (Table 2). Percentage biomass allocation to stems was greatest in the T100 treatment; values on stems were greater in the control than in the T33 and T67 treatments (Table 2). Finally, percentage biomass allocation to roots showed a slightly decreasing trend from the control to T33 and T67 treatments (Table 2); values determined in the T100 treatment for this organ were significantly lower than in the control and T33 treatment (Table 2).

The relative mass growth rate of seedlings was significantly affected by sand burial at the end of the experiment $\left(F_{3,56}=136.370, P<0.001\right)$. Greatest relative mass growth rate values of $0.031 \pm 0.001 \mathrm{mg} \mathrm{mg}^{-1}$ day $^{-1}$ were shown both in the T33 and T67 treatments (Fig. 4). These values were significantly greater than those found in the control (Fig. 4, $P<0.05$ ). Lowest relative mass rates of growth were determined on seedlings grown in the T100 treatment $\left(0.026 \pm 0.001 \mathrm{mg} \mathrm{mg}^{-1}\right.$ day $^{-1}$; Fig. 4).

\section{Discussion}

\subsection{Seedling survivorship in response to permanent sand burial}

In sandy land regions, seedlings might be buried at different depths between emergence and the end of the windy season, from late spring to early summer (Chen and Maun, 1999), and these sand burial effects were simulated in our experiment. After the 45 days buried by sand, partial burial with sand (to 33 or $67 \%$ of their height) did not influence the survival of sandy elm seedlings, as there was no mortality. These results agreed with studies of $\mathrm{He}$ et al. (2008), Liu et al. (2008), and Qu et al. (2012), which reported that survivorship of Artemisia halodendron, Corispermum macrocarpum, and Caragana microphylla was either maintained or increased by moderate sand burial in the Horqin Sandy Land. Survivorship of these shrubs, however, declined among plant species once their seedlings were covered by sand either equal to or more than $100 \%$ of their height, and this was also the case for our experiment. Survival decreased sharply by a mean of $15.6 \%$ when seedlings were completely buried (to $100 \%$ of their height), while deeper sand burial resulted 
Table 1. Dry biomass of leaves, stems, and roots for seedlings of Ulmus pumila var. sabulosa exposed to various sand burial treatments during a 45-day growth period. These treatments included sand burial of seedlings to a depth equivalent to 33 (T33), 67 (T67), or 100\% (T100) of the mean seedling height at the initiation of the study. Each histogram is the mean \pm 1 SE of $n=15$. Different letters in a row among seed burial depths are significantly different at $P<0.05$.

\begin{tabular}{|c|c|c|c|c|}
\hline Treatment & $\begin{array}{l}\text { Stem } \\
\text { mg }\end{array}$ & $\begin{array}{l}\text { Root } \\
\text { mg }\end{array}$ & $\begin{array}{l}\text { Leaf } \\
\mathrm{mg}\end{array}$ & $\begin{array}{l}\text { Total } \\
\text { mg }\end{array}$ \\
\hline T0 & $66.62 \pm 3.49 \mathrm{a}$ & $91.7 \pm 7.51 b$ & $160.63 \pm 9.15 b$ & $318.95 \pm 14.85 b$ \\
\hline T33 & $69.52 \pm 7.76 a$ & $104.59 \pm 9.89 \mathrm{c}$ & $195.55 \pm 11.54 \mathrm{c}$ & $369.65 \pm 17.27 \mathrm{c}$ \\
\hline T67 & $68.69 \pm 4.05 \mathrm{a}$ & $101.64 \pm 6.87 \mathrm{c}$ & $200.17 \pm 14.73 c$ & $372.5 \pm 15.74 \mathrm{c}$ \\
\hline T100 & $65.51 \pm 3.52 \mathrm{a}$ & $69.61 \pm 9.84 \mathrm{a}$ & $137.55 \pm 12.43 \mathrm{a}$ & $272.67 \pm 16.42 \mathrm{a}$ \\
\hline
\end{tabular}

Table 2. Percentage biomass allocation to leaves, stems, and roots on seedlings of Ulmus pumila var. sabulosa exposed to various sand burial treatments during a 45-day growth period. These treatments included sand burial of seedlings to a depth equivalent to 33 (T33), 67 (T67), or $100 \%$ (T100) of the mean seedling height at the initiation of the study. Each histogram is the mean \pm 1 SE of $n=15$. Different letters above histograms among seed burial depths are significantly different at $P<0.05$.

\begin{tabular}{llll}
\hline Treatment & $\begin{array}{l}\text { Stem } \\
\%\end{array}$ & $\begin{array}{l}\text { Root } \\
\%\end{array}$ & $\begin{array}{l}\text { Leaf } \\
\%\end{array}$ \\
\hline T0 & $20.9 \pm 1.4 \mathrm{~b}$ & $28.8 \pm 1.6 \mathrm{~b}$ & $50.3 \pm 1.4 \mathrm{~b}$ \\
T33 & $18.8 \pm 1.4 \mathrm{~b}$ & $28.3 \pm 1.4 \mathrm{~b}$ & $52.9 \pm 1.6 \mathrm{c}$ \\
T67 & $18.5 \pm 1.3 \mathrm{a}$ & $27.3 \pm 1.7 \mathrm{ab}$ & $54.2 \pm 2.4 \mathrm{c}$ \\
T100 & $24.1 \pm 2.4 \mathrm{c}$ & $25.5 \pm 2.4 \mathrm{c}$ & $50.4 \pm 2.4 \mathrm{c}$ \\
\hline
\end{tabular}

in no survival of sandy elm at all, as seedlings withered and rotted in the soil. That threshold offers a clear primary explanation for the absence of sandy elm seedling after relatively deep sand burial. Field survey in recent years has also shown that serious land degradation and reduction of vegetation cover has aggravated sand mobility, particularly in the leeward and semi-fixed dunes. Seedlings could successfully complete their periodic recruitments only by taking advantage of scarce favorable spatiotemporal chances (Tian et al., 2015; Wu et al., 2013). Maun (1981, 1997) and Disraeli (1984) also indicated that a certain tolerance to partial sand burial was an effective strategy for survival and subsequent establishment of seedlings in a sandy environments. Most seedlings of the grass Distichlis spicata died when completely covered by sand in North America (Brown, 1997; Li et al., 2015), while some Artemisia squarrosum seedlings still remained alive even though sand burial depths reached $266 \%$ of the initial seedling height in the Horqin Sandy Land (Li et al., 2015). Thus, compared with other species, seedlings of sandy elm showed a moderate resistance to sand burial. Harris and Davy (1987) and Perumal and Maun (2006) suggested that plant energy exhaustion and suppression of photosynthesis were implicated in the severely reduced intense radiation and high temperature to some extent. Seedlings of sandy elm have adapted to extreme con-

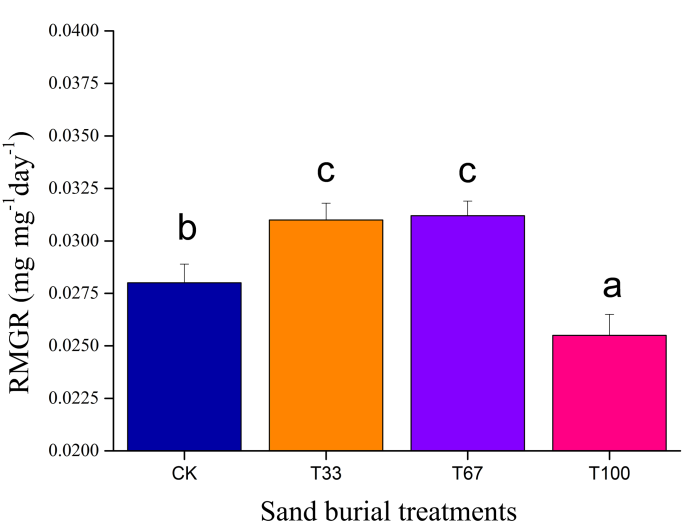

Figure 4. Relative mass growth rate (RMGR) on seedlings of Ulmus pumila var. sabulosa exposed to various sand burial treatments during a 45-day growth period. These treatments included sand burial of seedlings to a depth equivalent to 33 (T33), 67 (T67), or $100 \%$ (T100) of the mean seedling height at the initiation of the study. Each histogram is the mean $\pm 1 \mathrm{SE}$ of $n=15$. Different letters above histograms among seed burial depths are significantly different at $P<0.05$.

ditions, and previous research has confirmed that sandy elm had a higher transpiration rate and stomatal conductance with lower photosynthesis water-use efficiency and less sensitivity to high temperature and irradiance, compared with other native tree species such as Malus baccata, Prunus padus, and Pinus sylvestris, especially in the midday (Park et al., 2012).

\subsection{Effects of sand burial on seedling morphological traits}

Sand burial modifies the environments of living plants, forming new microhabitat available for seedlings (Disraeli, 1984; Sun et al., 2014). Plants would be expected to adjust their morphological performances and developments to maximize photosynthetic efficiency and sustain survival (Wang et al., 2014). Our results demonstrated that various seedling morphological traits (i.e., height, stem diameter, taproot length, total leaf area, dry biomass, partitioning of biomass to shoots and roots, RHGR and RMGR) were increased by partial burial, especially at T33. Thus seedling height of sandy elm 
was greater in the partially buried than in the unburied and completely buried treatments, which indicated that partial sand burial stimulated stem elongation. This might be explained by fact that the processes of growth and elongation benefit from improved water maintenance and nutrient uptake in these arid and semi-arid regions ( $\mathrm{Li}$ et al., 2015). In the Horqin Sandy Land, the dry sandy layer was shallower than $5 \mathrm{~cm}$ in semi-fixed dunes, so suitable sand burial depths could be beneficial in reducing soil temperature and maintaining moisture for the root system, which are both critical for seedling survival and resource capturing (Niu et al., 2015). Our findings were also consistent with previous research reported from Disraeli (1984), who reported that partial burial stimulated growth of Ammophila breviligulata in coastal dunes of northeastern North America. Belcher (1977) also determined that seedling heights of Rosa rugosa were higher in the partial than in the unburied and completely continuous sand burial treatments in a desert.

Seedling height growth rate was a critical parameter to determine the speed of growth. The greater RHGR of seedlings in the partial (T33 and T67) than in the unburied and completely buried treatments (T100) was an indication that partial burial did contribute to a greater seedling height after a 45-day growth period via accelerating the speed of growth in height. Nevertheless, the greatest seedling growth in height in the T33 treatment came from its greatest RHGR in this rather than any other treatments. Liu et al. (2008) and Miao et al. (2012) also found that shallow soil burial depths could promote the relative growth rates in height on Salix gordejevii, Artemisia wudanica, and Artemisia halodendron. However, it is not universally true as some species (e.g., Artemisia gmelinii) have decreased their growth rates as a result of sand burial (Liu et al., 2008). These findings confirmed that the phenotypic response to the degree of sand burial might be species-specific.

Compared with the unburied treatment, partial-burial treatments fostered increments in stem diameter and taproot length. Sun et al. (2014) also showed that seedling diameter and taproot length of Suaeda salsa were increased by a partial-burial treatment in the coastal marches of the Yellow River estuary, China. Caldwell et al. (1998) found that increases in taproot length were conducive to a greater nutrient and water uptake from deeper soil depths. In the partial burial, however, total leaf area was either similar to or lower than in the unburied treatment. This was in agreement with the results of Liu and Guo (2005), who noted that increasing depth of sand burial decreased the total leaf area of Caragana intermedia.

Changes of biomass allocation and relative mass growth rate are generally considered to be adaptive strategies to environmental changes, which are involved in successful seedling recruitments (Wu et al., 2013). Appropriate resource allocation is essential for plant establishment and growth (Bazzaz, 1997). Also, plants may shift resource allocation to minimize effects of external environmental changes (Maun,
1997; Ni et al., 2015). Numerous findings, especially those in sandy environments, have reported that plants could withstand episodes of sand burial by changing biomass allocation. Some species (e.g., Artemisia ordosia, Elymus farctus) may transfer biomass from underground to leaf and stem organs (Brown, 1997; Li et al., 2010), while others (e.g., Caragana microphylla, Nitraria sphaerocarpa) have either maintained or increased biomass allocation to roots ( $\mathrm{He}$ et al., 2008; Sykes and Wilson, 1990). In our experiment, it was somewhat surprising that no difference was observed in the dry biomass of seedling stems among all sand burial treatments. However, seedlings showed an increased stem diameter in the T33 sand burial treatment; similar to results of Zhao et al. (2015), changes possibly result from different water contents in diameter. Partial-burial treatments produced greater dry biomass for leaves, roots, and the whole seedlings in comparison with unburied and complete sand burial treatments. These results were consistent with previous studies's results that $67 \%$ burial of seedlings of the shrub Caragana intermedia resulted in a greater biomass allocation to leaves and stems than to roots, compared with values in the unburied control (Xu et al., 2013). Meanwhile, there was a trend of increasing aboveground parts (e.g., leaves) and a decreasing belowground allocation with increasing burial depth for sandy elm seedlings. Nearly $50 \%$ of the total seedling biomass corresponded to leaves. This indicated the maintenance of leaf area for photosynthesis and evapotranspiration were important for sandy elm seedlings exposed to high temperature and irradiance in the growing season (Dulamsuren et al., 2009; Li et al., 2003; Park et al., 2012). The relative investment in root was slightly decreased, which indicated, on the one hand, that greater soil moisture availability weakened the dependence on root function and, on the other hand, the plant's need to divert biomass aboveground for light interception and net assimilation rate (Maun, 1994; Sun et al., 2010; Wang et al., 2014).

Relative mass growth rates measure the mean efficiency rate for producing new biomass (Walck et al., 1999). Dalling and Hubbell (2002) showed that seedling growth rate was a better determinant of successful seedling establishment than biomass. In our experiment, relative mass growth rates were higher in the partial than in the other treatments, indicating that moderate sand burials were beneficial for biomass increase. However, all relative mass growth rates were small compared with those of other plant species (e.g., Artemisia wudanica, Solidago shortii, and Solidago altissima) in the same area. This suggested the relatively lower biomass accumulation on sandy elm seedlings during the first growing season, putting these seedlings at a disadvantage in resource competition and coexistence with other species (Brown, 1997; Liu et al., 2014; Wu et al., 2013). Reduced dry-matter accumulation could also have contributed to increased mortality.

Although there were striking effects on biomass accumulation and allocation, reflecting the plasticity of various 
morphological traits, partial sand burial treatments did not change the survivorship, and these treatments facilitated individual seedling growth and population regeneration through phenotypic plasticity or various morphological traits. Our study, however, was conducted in a common garden, where there exist some limitations compared with in the wild. Under natural rangeland conditions, some factors (e.g., abrasion of plant tissues by sand grains, grazing by herbivores and granivores) might reduce or eliminate some of the positive effects of the partial-burial treatments (Dulamsuren et al., 2009; Jeffreyt et al., 2009). Furthermore, we found some evidence of allometry of each plant proportion with increasing seedling age in our experiment. Therefore, more comprehensive studies on physiological and biochemical mechanisms relating to sandy elm seedling survivorship and performance under sand burial conditions at different growth stages are necessary in future research.

\section{Conclusions}

Sand burial affected seedling survivorship, growth, and biomass allocation of Ulmus pumila var. sabulosa through phenotypic plasticity of morphological traits. Seedlings of sandy elm showed adaptive responses to moderate sand burial, consistent with its evolution in sandy environment. Partial sand burial treatment did not influence seedling survivorship, but complete sand burial significantly increased mortality. Compared with the unburied treatment, seedling height, relative height growth rates, taproot length, total biomass, and relative mass growth rates were stimulated by partial burial with sand. At the same time, percentage biomass allocation of seedlings was changed, diverting more biomass to aboveground organs (e.g., leaves) to sustain normal photosynthesis and evapotranspiration. Complete sand burial after seedling emergence, however, inhibited their growth and even resulted in seedling death. Consequently burial depths should be controlled by making enclosures and increasing vegetation coverage to facilitate regeneration or re-establishments of sandy elm. The observed variation in all parameters has defined the tolerance of Ulmus pumila var. sabulosa to sandy environments and its capacity to acclimate to them. Hence our research provides theoretical support for recruitments in sandy sparse-elm woodlands.

Acknowledgements. This study was supported by the National Natural Science Foundation of China (31370706) and the Wulanaodu Desertification Experimental Station of the Institute of Applied Ecology, Chinese Academy of Sciences. We thank Yongming Luo, Xuehua Li, Quanlai Zhou, Hongmei Wang, Meiyu Jia, Ya Liu,and Xu Han for assistance during the experiment. Thanks to Anthony J. Davy from the University of East Anglia for guiding the statistical analysis and language polishing of the original manuscript.
Edited by: Artemi Cerdà

Reviewed by: four anonymous referees

\section{References}

Bazzaz, F. A.: Allocation of Resources in Plants: State of the Science and Critical Questions, in: Plant Resource Allocation, Academic Press, San Diego, 1997.

Belcher, C. R.: Effect of sand cover on the survival and vigor of Rosa rugosa Thunb, Int. J. Biometeorol., 21, 276-280, 1977.

Bellamy, P. H., Loveland, P. J., Bradley, R. I., Lark, R. M., and Kirk, G. J. D.: Carbon losses from all soils across England and Wales 1978-2003, Nature, 437, 245-248, 2005.

Berendse, F., van Ruijven, J., Jongejans, E., and Keesstra, S.: Loss of Plant Species Diversity Reduces Soil Erosion Resistance, Ecosystems, 18, 881-888, 2015.

Borreli, P., Panagos, P., Ballabio, C., Lugato, E., Weynants, M., and Montanaalla, L.: Towards a Pan-European assessment of land susceptibiity to wind erosion, Land Degrad. Dev., 27, 10931105, 2016.

Brevik, E. C., Cerdà, A., Mataix-Solera, J., Pereg, L., Quinton, J. N., Six, J., and Van Oost, K.: The interdisciplinary nature of SOIL, SOIL, 1, 117-129, doi:10.5194/soil-1-117-2015, 2015.

Brown, J. F.: Effects of Experimental Burial on Survival, Growth, and Resource Allocation of Three Species of Dune Plants, J. Ecol., 85, 151-158, 1997.

Caldwell, M. M., Dawson, T. A., and Richards, J. H.: Hydraulic lift: Consequences of water efflux from the roots of plants, Oecologia, 113, 151-161, 1998.

Cao, C. Y., Jiang, D. M., Teng, X. H., Jiang, Y., Liang, W. J., and Cui, Z. B.: Soil chemical and microbiological properties along a chronosequence of Caragana microphylla Lam. plantations in the Horqin sandy land of Northeast China, Appl. Soil Ecol., 40, 78-85, 2008.

Cao, C. Y., Jiang, S. Y., Zhang, Y. Y., Zhang, F. H., and Han, X. S.: Spatial variability of soil nutrients and microbiological properties after the establishment of leguminous shrub Caragana microphylla Lam. plantation on sand dune in the Horqin Sandy Land of Northeast China, Ecol. Eng., 37, 1467-1475, 2011.

Cerdà, A.: The influence of aspect and vegetation on seasonal changes in erosion under rainfall simulation on a clay soil in Spain, Can. J. Soil Sci., 78, 321-330, 1998.

Chen, H. and Maun, M. A.: Effects of sand burial depth on seed germination and seedling emergence of Cirsium pitcheri, Plant Ecol., 140, 53-60, 1999.

Cheplick, G. P. and Grandstaff, K.: Effects of sand burial on purple sandgrass (Triplasis purpurea): the significance of seed heteromorphism, Plant Ecol., 133, 79-89, 1997.

Colazo, J. C. and Buschiazzo, D.: The impact of agriculture on soil texture due to wind erosion, Land Degrad. Dev., 26, 62-70, 2015.

Disraeli, D. J.: The effect of sand deposits on the growth and morphology of Ammophila Breviligulata, J. Ecol., 72, 145-154, 1984.

Dulamsuren, C., Hauck, M., Nyambayar, S., Bader, M., Osokhjargal, D., Oyungerel, S., and Leuschner, C.: Performance of Siberian elm (Ulmus pumila) on steppe slopes of the northern Mongolian mountain taiga: Drought stress and herbivory in mature trees, Environ. Exp. Bot., 66, 18-24, 2009. 
Foley, J. A., DeFries, R., Asner, G. P., Barford, C., Bonan, G., Carpenter, S. R., Chapin, F. S., Coe, M. T., Daily, G. C., Gibbs, H. K., Helkowski, J. H., Holloway, T., Howard, E. A., Kucharik, C. J., Monfreda, C., Patz, J. A., Prentice, I. C., Ramankutty, N., and Snyder, P. K.: Global Consequences of Land Use, Science, 309, 570-574, 2005.

Gabarrón-Galeote, M. A., Martínez-Murillo, J. F., Quesada, M. A., and Ruiz-Sinoga, J. D.: Seasonal changes in the soil hydrological and erosive response depending on aspect, vegetation type and soil water repellency in different Mediterranean microenvironments, Solid Earth, 4, 497-509, doi:10.5194/se-4-497-2013, 2013

Gao, Y., Dang, X., Yu, Y., Li, Y., Liu, Y., and Wang , J.: Effects of tillage methods on soil carbon and wind erosion, Land Degrad. Dev., 27, 583-591, 2015.

Harris, D. and Davy, A. J.: Seedling Growth in Elymus farctus after Episodes of Burial with Sand, Ann. Bot., 60, 587-593, 1987.

He, Y. H., Zhao, H. L., Zhao, X. Y., and Liu, X. P.: Effects of different sand burial depths on growth and biomass allocation in Caragana microphylla seedlings, Arid Land Geogr., 31, 701706, 2008

Jeffreyt, B., Bobbie, M. M., Johnj, B., Dennisc, G., Robertj, L., and Jhonathane, E.: Sand abrasion Injury and biomass partitioning in cotton seedlings, Agr. J., 101, 1297-1303, 2009.

Jiang, D. M., Liu, Z. M., Cao, C. Y., Kou, Z. W., and Wang, R. Y.: Desertification and ecological restoration of Keerqin Sandy Land, China environmental science Press, Beijing, 2003.

Jiang, D. M., Tang, Y., and Busso, C. A.: Effects of vegetation cover on recruitment of Ulmus pumila L. in Horqin Sandy Land, northeastern China, J. Arid Land, 6, 343-351, 2013.

Li, J., Qu, H., Zhao, H. L., Zhou, R. L., Yun, J., and Pan, C. C.: Growth and physiological responses of Agriophyllum squarrosum to sand burial stress, J. Arid Land, 7, 94-100, 2015.

Li, S. L., Werger, M. A., Zuidema, P., Yu, F.-H., and Dong, M.: Seedlings of the semi-shrub Artemisia ordosica are resistant to moderate wind denudation and sand burial in Mu Us sandland, China, Trees, 24, 515-521, 2010.

Li, X. H., Jiang, D. M., Zhou, Q. L., and Oshida, T.: Soil seed bank characteristics beneath an age sequence of Caragana microphylla shrubs in the Horqin Sandy Land region of northeastern China, Land Degrad. Dev., 25, 236-243, 2014.

Li, Y. G., Jiang, G. M., Niu, S. L., Liu, M. Z., Peng, Y., Yu, S. L., and Gao, L. M.: Gas Exchange and Water Use Efficiency of Three Native Tree Species in Hunshandak Sandland of China, Photosynthetica, 41, 227-232, 2003.

Liu, B., Liu, Z. M., and Guan, D. X.: Seedling growth variation in response to sand burial in four Artemisia species from different habitats in the semi-arid dune field, Trees, 22, 41-47, 2008.

Liu, B., Liu, Z. M., Lü, X. T., Maestre, F. T., and Wang, L. X.: Sand burial compensates for the negative effects of erosion on the dune-building shrub Artemisia wudanica, Plant Soil, 374, 263 273,2014

Liu, H. and Guo, K.: The impacts of sand burial on seedling development of Caragana intermedia, Acta Ecologica Sinica, 25, 2550-2555, 2005.

Liu, Z. M., Zhu, J. L., and Deng, X.: Arrival vs. retention of seeds in bare patches in the semi-arid desertified grassland of Inner Mongolia, northeastern China, Ecol. Eng., 49, 153-159, 2012.
Ma, C. G.: A Provenance Test of White Elm (Ulmus-Pumila L) in China, Silvae Genet, 38, 37-44, 1989.

Maun, M. A.: Adaptations enhancing survival and establishment of seedlings on coastal dune systems, Vegetatio, 111, 59-70, 1994.

Maun, M. A.: Adaptations of plants to burial in coastal sand dunes, Canadian Journal of Botany-Revue Canadienne De Botanique, 76, 713-738, 1997.

Maun, M. A. and Lapierre, J.: Effects of Burial by Sand on Seed Germination and Seedling Emergence of Four Dune Species, Am. J. Bot., 73, 450-455, 1986.

Miao, R. H., Jiang, D. M., Musa, A., Zhou, Q. L., Guo, M. X., and Wang, Y. C.: Effectiveness of shrub planting and grazing exclusion on degraded sandy grassland restoration in Horqin sandy land in Inner Mongolia, Ecol. Eng., 74, 164-173, 2014.

Miner, B. G., Sultan, S. E., Morgan, S. G., Padilla, D. K., and Relyea, R. A.: Ecological consequences of phenotypic plasticity, Trends Ecol. Evol., 20, 685-692, 2005.

Ni, J., Luo, D. H., Xia, J., Zhang, Z. H., and Hu, G.: Vegetation in karst terrain of southwestern China allocates more biomass to roots, Solid Earth, 6, 799-810, doi:10.5194/se-6-799-2015, 2015.

Niu, C. Y., Musa, A., and Liu, Y.: Analysis of soil moisture condition under different land uses in the arid region of Horqin sandy land, northern China, Solid Earth, 6, 1157-1167, doi:10.5194/se6-1157-2015, 2015.

Park, Y. D., Lee, D. K., Batkhuu, N. O., Tsogtbaatar, J., Combalicer, M. S., Go, E., Park, and Su, Y. W.: Woody Species Variations in Biomass Allocation, Photosynthetic WUE and Carbon Isotope Composition under Natural Drought Condition in Mongolia, J. Environ. Sci. Manag., 29-37, 2012.

Perumal, V. J. and Maun, M. A.: Ecophysiological response of dune species to experimental burial under field and controlled conditions, Plant Ecol., 184, 89-104, 2006.

Qian, J. Q., Liu, Z. M., Hatier, J. H. B., and Liu, B.: The Vertical Distribution of Soil Seed Bank and Its Restoration Implication in an Active Sand Dune of Northeastern Inner Mongolia, China, Land Degrad. Dev., 27, 305-315, 2015.

Qiu, S. W.: Study on the formation and evolution of Horqin Sandy Land, Scientia Geographica Sinica, 9, 317-328, 1989.

Qu, H., Zhao, H. L., Zhou, R. L., Zuo, X. A., Luo, Y., Wang, J. G., and Barron, J. O.: Effects of sand burial on the survival and physiology of three psammophytes of Northern China, African J. Biotechnol., 11, 4518-4529, 2012.

Schlütz, F., Dulamsuren, C., Wieckowska, M., Mühlenberg, M., and Hauck, M.: Late Holocene vegetation history suggests natural origin of steppes in the northern Mongolian mountain taiga, Palaeogeogr. Palaeocl., 261, 203-217, 2008.

Shi, L., Zhang, Z. J., Zhang, C. Y., and Zhang, J. Z.: Effects of sand burial on survival, growth, gas exchange and biomass allocation of Ulmus pumila seedlings in the Hunshandak Sandland, China, Ann. Bot., 94, 553-560, 2004.

Smith, P., Cotrufo, M. F., Rumpel, C., Paustian, K., Kuikman, P. J., Elliott, J. A., McDowell, R., Griffiths, R. I., Asakawa, S., Bustamante, M., House, J. I., Sobocká, J., Harper, R., Pan, G., West, P. C., Gerber, J. S., Clark, J. M., Adhya, T., Scholes, R. J., and Scholes, M. C.: Biogeochemical cycles and biodiversity as key drivers of ecosystem services provided by soils, SOIL, 1, 665685, doi:10.5194/soil-1-665-2015, 2015. 
Sokal, R. and Rohlf, F.: Biometry, 3rd Edn., WH Freman and Company, New York, 1995.

Sun, Z. G., Mou, X. G., Lin, G. H., Wang, L. L., Song, H. L., and Jiang, H.: Effects of sediment burial disturbance on seedling survival and growth of Suaeda salsa in the tidal wetland of the Yellow River estuary, Plant Soil, 337, 457-468, 2010.

Sun, Z. G., Song, H. L., Sun, W. G., and Sun, J. K.: Effects of continual burial by sediment on morphological traits and dry mass allocation of Suaeda salsa seedlings in the Yellow River estuary: An experimental study, Ecol. Eng., 68, 176-183, 2014.

Sykes, M. T. and Wilson, J. B.: An experimental investigation into the response of New Zealand sand dune species to different depths of burial by sand, Acta Botanica Neerlandica, 39, 171$181,1990$.

Tang, J., Busso, C.A., Jiang, D. M., Wang, Y. C., Wu, D. F., Musa, A., Miao, R. H., and Miao, C. P.: Seed Burial Depth and Soil Water Content Affect Seedling Emergence and Growth of Ulmus pumila var. sabulosa in the Horqin Sandy Land, Sustainability, 8, 68-77, 2016.

Tang, J., Jiang, D. M., and Wang, Y. C.: A review on the process of seed-seedling regeneration of Ulmus pumila in sparse forest grassland, Chinese J. Ecol., 33, 1114-1120, 2014.

Tang, Y., Jiang, D. M., and Lü, X. T.: Effects of Exclosure Management on Elm (Ulmus Pumila) Recruitment in Horqin Sandy Land, Northeastern China, Arid Land Res. Manag., 28, 109-117, 2013.

Tian, F. P., Liu, Y., Wu, G. L., and Shi, S. L.: Seedling recruitment of forb species under experimental microhabitats in alpine grassland, Pakistan J. Bot., 47, 2127-2134, 2015.

Verheijen, F. G. A., Jones, R. J. A., Rickson, R. J., and Smith, C. J.: Tolerable versus actual soil erosion rates in Europe, Earth-Sci. Rev., 94, 23-38, 2009.

Walck, J. L., Baskin, J. M., and Baskin, C. C.: Relative competitive abilities and growth characteristics of a narrowly endemic and a geographically widespread Solidago species (Asteraceae), Am. J. Bot., 86, 820-828, 1999.

Wang, D., Zhu, Y. J., Wu, G. L., and Feng, J.: Seedling performance within eight different seed-size alpine forbs under experimentation with irradiance and nutrient gradients, Pakistan J. Bot., 46, 1261-1268, 2014.

Wang, J., Zhou, R. L., Zhao, H. L., Zhao, Y., and Hou, Y.: Growth and physiological adaptation of Messerschmidia sibirica to sand burial on coastal sandy, Acta Ecologica Sinica, 32, 4291-4299, 2012.
Wang, K. B., Deng, L., Ren, Z. P., Li, J. P., and Shangguan, Z. P.: Grazing exclusion significantly improves grassland ecosystem $\mathrm{C}$ and $\mathrm{N}$ pools in a desert steppe of Northwest China, Catena, 137, 441-448, 2016.

Wang, T., Xue;, X., Zhou;, L., and Guo, J.: Combating aeolian desertification in northern China, Land Degrad. Dev., 26, 118-132, 2015.

Wu, G. L., Feng, J., Shi, Z. H., and Du, G. Z.: Plant seedling performance traits impact on successful recruitment in various microhabitats for five Alpine Saussurea species, Pakistan J. Bot., 45, 61-71, 2013.

Xu, L., Huber, H., During, H. J., Dong, M., and Anten, N. P. R.: Intraspecific variation of a desert shrub species in phenotypic plasticity in response to sand burial, New Phytol., 199, 991-1000, 2013.

Yan, Q. L. Liu, Z. M., Zhu, J. J., Luo, Y. M., Wang, H. M., and Jiang, D.: Structure, Pattern and Mechanisms of Formation of Seed Banks in Sand Dune Systems in Northeastern Inner Mongolia, China, Plant Soil, 277, 175-184, 2005.

Yang, H. L., Cao, Z. P., Dong, M., Ye, Y. Z., and Huang, Z. Y.: Effects of sand burying on caryopsis germination and seedling growth of Bromus inermis Leyss, Chinese J. Appl. Ecol., 18, 2438-2443, 2007.

Yang, L. M., Zhou, G. S., Wang, G. H., and Wang, Y. H.: Effect of human activities on soil environment and plant species diversity of elm sparse woods, J. Appl. Ecol., 14, 321-325, 2003.

Zhang, T. H., Zhao, H. L., Li, S. G., Li, F. R., Shirato, Y., Ohkuro, T., and Taniyama, I.: A comparison of different measures for stabilizing moving sand dunes in the Horqin Sandy Land of Inner Mongolia, China, J. Arid Environ., 58, 203-214, 2004.

Zhao, H. L., Li, J., Zhou, R. L., Qu, H., Yun, J., and Pan, C. C.: Effects of Sand Burial on Growth Properties of Pinus sylvestnis var.mongolica, J. Desert Res., 35, 60-65, 2015.

Zhao, W. Z., Li, Q. Y., and Fang, H. Y.: Effects of sand burial disturbance on seedling growth of Nitraria sphaerocarpa, Plant Soil, 295, 95-102, 2007. 